\title{
Integrated rock typing and pore facies analyses in a heterogeneous carbonate for saturation height modelling, a case study from Fahliyan Formation, the Persian Gulf
}

\author{
Rasoul Ranjbar-Karami ${ }^{1,2} \cdot$ Parisa Tavoosi Iraj ${ }^{1} \cdot$ Hamzeh Mehrabi ${ }^{1}$
}

Received: 8 December 2020 / Accepted: 8 March 2021 / Published online: 20 March 2021

(c) The Author(s) 2021

\begin{abstract}
Knowledge of initial fluids saturation has great importance in hydrocarbon reservoir analysis and modelling. Distribution of initial water saturation (Swi) in 3D models dictates the original oil in place (STOIIP), which consequently influences reserve estimation and dynamic modelling. Calculation of initial water saturation in heterogeneous carbonate reservoirs always is a challenging task, because these reservoirs have complex depositional and diagenetic history with a complex pore network. This paper aims to model the initial water saturation in a pore facies framework, in a heterogeneous carbonate reservoir. Petrographic studies were accomplished to define depositional facies, diagenetic features and pore types. Accordingly, isolated pores are dominant in the upper parts, while the lower intervals contain more interconnected interparticle pore types. Generally, in the upper and middle parts of the reservoir, diagenetic alterations such as cementation and compaction decreased the primary reservoir potential. However, in the lower interval, which mainly includes high-energy shoal facies, high reservoir quality was formed by primary interparticle pores and secondary dissolution moulds and vugs. Using huge number of primary drainage mercury injection capillary pressure tests, we evaluate the ability of FZI, r35Winland, r35Pittman, FZI* and Lucia's petrophysical classes in definition of rock types. Results show that recently introduced rock typing method is an efficient way to classify samples into petrophysical rock types with same pore characteristics. Moreover, as in this study MICP data were available from every one meter of reservoir interval, results show that using FZI* method much more representative sample can be selected for SCAL laboratory tests, in case of limitation in number of SCAL tests samples. Integration of petrographic analyses with routine (RCAL) and special (SCAL) core data resulted in recognition of four pore facies in the studied reservoir. Finally, in order to model initial water saturation, capillary pressure data were averaged in each pore facies which was defined by FZI* method and using a nonlinear curve fitting approach, fitting parameters (M and C) were extracted. Finally, relationship between fitting parameters and porosity in core samples was used to model initial water saturation in wells and between wells. As permeability prediction and reservoir rock typing are challenging tasks, findings of this study help to model initial water saturation using log-derived porosity.
\end{abstract}

Keywords Petrophysical rock typing $\cdot$ FZI* $\cdot$ Pore facies $\cdot$ Heterogeneous carbonate reservoir $\cdot$ Water saturation modelling

\begin{tabular}{|c|c|}
\hline \multicolumn{2}{|c|}{ Abbreviations } \\
\hline DRT & Discrete rock type \\
\hline GHE & Global hydraulic element \\
\hline FWL & Free water level \\
\hline FZI & Flow zone indicator \\
\hline FZI* & Flow zone indicator star \\
\hline $\mathrm{K}$ & Permeability \\
\hline
\end{tabular}

Rasoul Ranjbar-Karami

Ranjbar_rasoul@ut.ac.ir

1 Geology Department, University of Tehran, Tehran, Iran

2 Pars Petro Zagros (PPZ) Co, Tehran, Iran

$\begin{array}{ll}\text { LC } & \text { Lorenz coefficient } \\ \text { mD } & \text { Millidarcy } \\ \text { MF } & \text { Microfacies } \\ \text { MICP } & \text { Mercury injection capillary pressure } \\ \text { PC } & \text { Capillary pressure } \\ \text { PF } & \text { Pore facies } \\ \text { PTS } & \text { Pore throat size } \\ \text { PTSD } & \text { Pore throat size distribution } \\ \text { RCAL } & \text { Routine core analysis } \\ \text { RNF } & \text { Rock fabric number } \\ \text { RT } & \text { Rock type } \\ \text { SCAL } & \text { Special core analysis } \\ \text { STOIIP } & \text { Original oil in place }\end{array}$




$\begin{array}{ll}\text { SW } & \text { Water saturation } \\ \text { Swi } & \text { Initial water saturation } \\ \phi & \text { Porosity }\end{array}$

\section{Introduction}

Calculation of initial water $\left(\mathrm{S}_{\mathrm{wi}}\right)$ and hydrocarbon $\left(1-\mathrm{S}_{\mathrm{wi}}\right)$ saturations has important implications in petrophysical analyses of petroleum reservoirs (Cannon 2015; Kennedy 2015; Tiab et al. 2015). Reservoir modellers use initial hydrocarbon saturation in order to model past and future behaviour of the reservoir and consequently to make an appropriate development plan (Ghedan et al. 2004; Esther et al. 2015). Generally, a combination of resistivity log data, porosity, water resistivity and volume of shale is required to calculate the water saturation in each well (Kennedy 2015; Tiab et al. 2015). However, limited log-derived water saturations are not suitable for modelling, especially in reservoir with long production history and thick transition zone.

The common and accepted method for initial saturation modelling is based on special core analysis (SCAL) and capillary pressure (PC) tests (Jamiolahmady et al. 2007; ZHAO et al. 2008; Kumar et al. 2011). The capillary pressure against gravity force controls the fluids distribution above the FWL in a reservoir. When capillary pressure data are available, water saturation can be calculated at any point above the FWL (Tiab et al. 2015). This process is called saturation height modelling (Al-Khaldi et al. 2012; Yong et al. 2012). However, in a real reservoir, water saturation does not show a single idealized vertical profile showing increase in hydrocarbon saturation in predictable pattern upward from free water level (FWL), which can be seen in text books.
This is because of the heterogeneous nature of porous media (Lalicata et al. 2012; Moore et al. 2013; Ma 2019). Changes in lithofacies, storage and flow capacities and pore characteristics (i.e. pore types, size, shape and geometry) will affect the water saturation vertical profile and its three-dimensional distribution in subsurface area (Aliakbardoust et al. 2013). Figure 1 represents a schematic diagram showing different rock types with different saturations versus height profile in a heterogeneous reservoir and highlights using appropriate rock typing approach. As it can be seen from this figure, Point "A" located in the transition zone must be classified as rock type 1, which is prone to be classified in rock type 4 with implementing wrong rock typing method.

Carbonate reservoir rocks are heterogeneous by nature in various scales because of their formation processes and complex diagenesis history (Lucia 2007; Moore et al. 2013; Mehrabi et al. 2015; Tavoosi-Iraj et al. 2021). Consequently, the water saturation height functions are more complex in carbonate reservoir rocks than the clastic reservoirs (Lian et al. 2016; Ma 2019). Accordingly, the more reservoir heterogeneity results in higher possibility of inaccurate calculation of initial hydrocarbon saturation (Cuddy et al. 1993; Al Waili 2009; Chudi et al. 2010). Therefore, using an adequate rock typing method is vital for saturation modelling in a reservoir (Askari et al. 2011; Mirzaei-Paiaman et al. 2015). Net-pay cut-off determination, core sample selections for SCAL tests and permeability prediction in uncored intervals are among the other important applications of rock typing (Amaefule et al. 1993; Abbaszadeh et al. 1996; MirzaeiPaiaman et al. 2015; Mirzaei-Paiaman et al. 2016). FZI, r35Winland, r35Pittman, FZI* and Lucia's petrophysical classes (Kolodzie Jr et al. 1980; Pittman 1992; Amaefule et al. 1993; Lucia et al. 2001; Mirzaei-Paiaman et al. 2018)
Fig. 1 Sketch of different rock types in a reservoir. Note that rock typing with fix ranges of irreducible water saturation results in placement of. point " $\mathrm{A}$ " in rock type 4 which must be classified as rock type 1(adapted from DakhelpourGhoveifel et al. 2019)

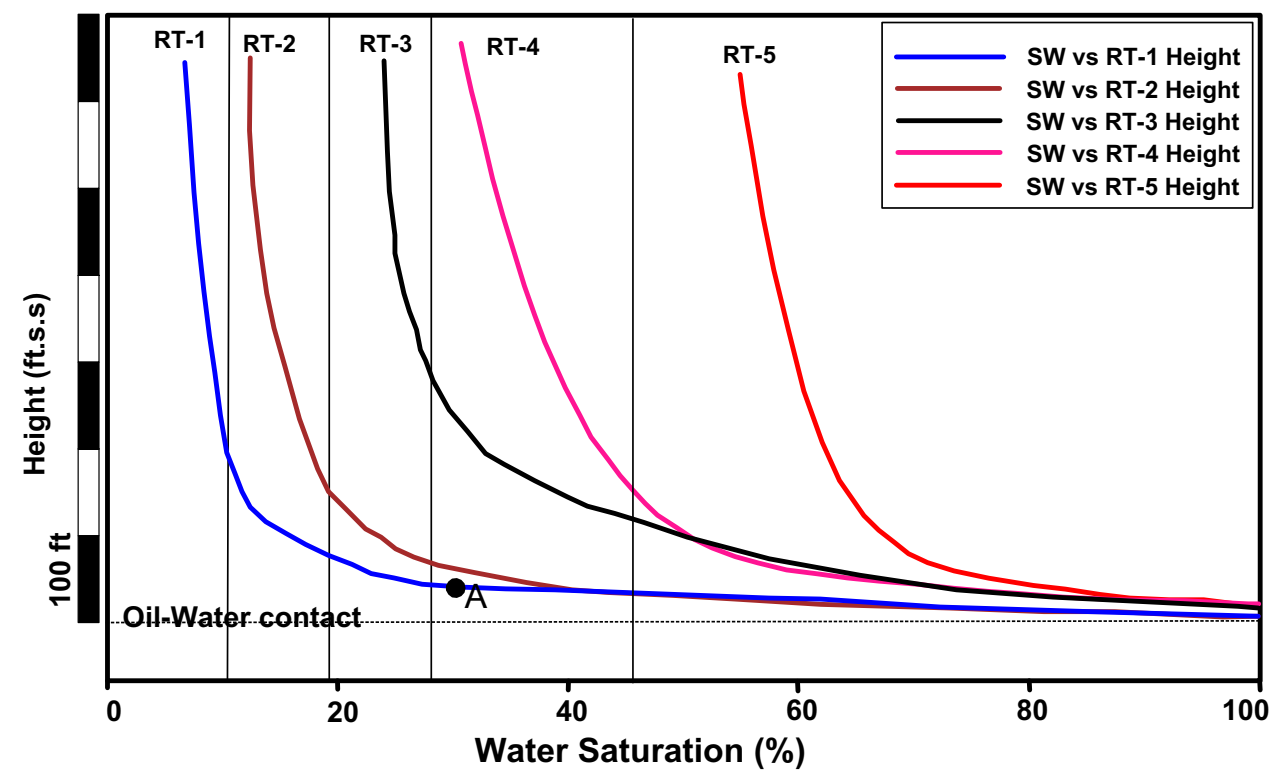


are indices that utilize porosity and permeability to separate reservoir into distinct rock type. However, their efficiency needs to be checked in every reservoir. As characterization of pore heterogeneity is critical to the prediction of flow behaviour under reservoir conditions, this study investigates pore geometry in Fahliyan Formation to model initial water saturation.

Over the years, various mathematical formulas are introduced and used to describe variations in Sw with height and reservoir properties. Leverett (1941) introduced J-Leverett function to normalize all the capillary pressure versus saturation curves into a single curve. Aufricht et al. (1957) were first to relate $\mathrm{Pc}$ and $\mathrm{Sw}$ data from core measurements to porosity and permeability information. Heseldin et al. (1974) modified the Aufricht et al. 1957 by relating the porosity to hydrocarbon bulk volume. Alger et al. (1989) modified the Heseldin's method by proposing a multilinear regression to relate Pc to porosity or permeability and used the term Cap-Log method. Gradually, new saturation functions were introduced which were written based on height and permeability (Johnson et al. 1987; Sondena 1992), height and porosity (Cuddy et al. 1993) or merely based on height (Skelt et al. 1995).

In recent years, researchers have focused on using different saturation functions based on various frameworks such as lithofacies and rock typing of reservoir interval based on different indices (Kamalyar et al. 2013; Omeke et al. 2014; Lian et al. 2016; Kundu et al. 2017). However, it should be noted that permeability prediction and rock typing are challenging issues in heterogeneous formations.

Recently, Lian et al. (2016) have used the idea of capillary height and Pittman r35 to map of water saturation. A similar approach has been adapted by Dakhelpour-Ghoveifel et al. (2019). They have used capillary pressure curves and specific borders between rock types to calculate water saturation and assign rock type to grids in transition zone. Here, we used pore facies and parameter fitting approach to model water saturation.

This paper aims to determine initial water saturation in a heterogeneous carbonate reservoir in northwest of Persian Gulf. First, a detailed petrographic analysis on 388 thin sections, taken from $290 \mathrm{~m}$ of Fahliyan Formation, resulted in the definition of six microfacies, dominant diagenetic events and types of pores in this reservoir. Then, in order to evaluate reservoir quality and pore geometry, reservoirs rocks were classified into groups based on the different indices and appropriate methods were selected. As pore system properties controls fluid saturation and the reservoir rock quality, we used pore types as a framework to extract fitting parameters and their relationship with porosity in core plugs. Then, saturation height modelling was conducted using the extracted equation, and its constants were modified based on porosity in core samples. In this way, substitution of core porosity with log-derived initial water saturation can be calculated anywhere in the reservoir.

The advantage of this method is that it uses rock types only in plug samples scale to extract fitting parameters. Therefore, calculated initial water saturation from this method can be used for reservoir simulation and reservoir rock typing in reservoir scale using methods introduced by other researchers (Dakhelpour-Ghoveifel et al. 2019). On the contrary, this method utilizes vast SCAL and RCAL core analysis results and it is not applicable in fields without core samples.

First, the reservoir stratigraphy is presented. Then, used data and methods are described. Thereafter, in "Results" section, microfacies, dominant diagenetic events and types of pores were recognized. Next, pore facies were determined through implementing different methods on our data set and finally discussion and conclusions are presented.

\section{Reservoir stratigraphy}

The studied field is located in northwest of the Persian Gulf (Fig. 2a). The main reservoir rock of this field is Berriasian-Valanginian strata known as the Fahliyan Formation, which is partly equivalent to the Yamama, Minagish and Manifa Formations in the Middle East (Fig. 2b). This formation unconformably overlies the Hith evaporites and is conformably overlain by the tight and micritic limestones of the Gadvan Formation (Fig. 2b). In the studied field, based on the reservoir quality, Fahliyan Formation has been divided into three members including lower Fahliyan (LF) with the best reservoir quality that is equivalent to the Manifa Formation in surrounding areas, the middle Fahliyan (MF) representing the major reservoir interval and the upper Fahliyan (UF) with poor reservoir quality (Fig. 4). According to previous studies, this formation and its equivalents were deposited on homoclinal carbonate ramps on the NE margin of the Arabian Plate (Adabi et al. 2010; Jamalian et al. 2011; Jamalian et al. 2014; Noori et al. 2019). It is mainly composed of grey to brown, massive, oolitic to pellety limestones with minor brecciation at the basal parts (James et al. 1965). The extensive development, moderate to good storage and flow capacities and proximity to the organic-rich Sargelu and Garau Formations all make this formation as one of the most important reservoir rocks in the Zagros area and the Persian Gulf region (Setudehnia 1978; Ghazban 2007). 

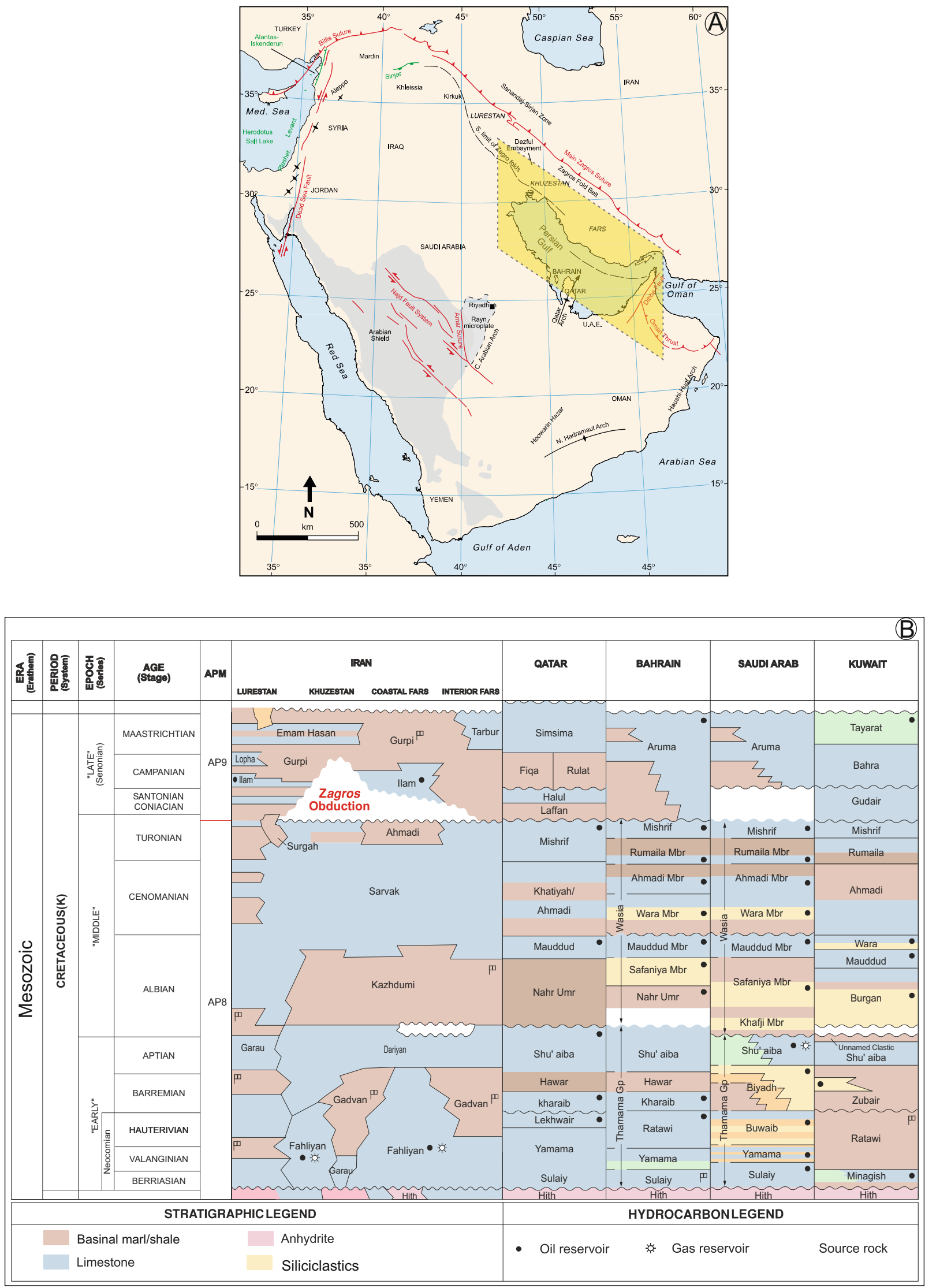
4 Fig. 2 a Location map of the Middle East, the orange rectangular is representing study area. (b) Stratigraphic column of the Early Cretaceous strata in south of Iran and surrounding areas (adapted from petroleum geo-service, 2001; http://www.pgs.com)

\section{Materials and methods}

This research is based on a dataset from the reservoir interval of the Fahliyan Formation in an oilfield selected from the northwest of Persian Gulf (Fig. 2a). In particular, the dataset of this study comprises 290 m of core samples and 388 thin sections for petrographic analyses. All samples were dyed by blue epoxy resin in order to differentiate pore types. In particular, all thin section samples were analysed by petrographic microscope for identification of allochems, textural classification (Embry et al. 1971), depositional facies and environments (Flügel 2013), as well as lithology and diagenetic processes. More than 1460 core plug samples, from three recently drilled wells, were used for routine core analysis (RCAL) parameters including porosity, permeability and grain density. These data were used in order to conduct reservoir rock typing and reservoir quality assessment. Primary drainage mercury injection capillary pressure data of 211 core plug samples, measured using CMS-300 apparatus, were used in this study. In all samples, pertinent helium porosity and permeability (corrected for the Klinkenberg effect) are measured at overburden pressure condition.

Conventional full set of wireline logs including spectral gamma ray, density, neutron, sonic and resistivity logs was available wells. Petrophysical logs were evaluated using optimizing petrophysical approach in this study. Results of petrophysical evaluation were used to calculate porosity in uncored wells and water saturation modelling.

In this study, reservoir rocks were classified into specific pore types using combination of petrographic studies and different rock typing methods. The identified rock types were used as a good indicator of reservoir quality and pore geometry index. In this study, we compare the results from and Winland r35 (Kolodzie Jr et al. 1980), Pittman r35 (Pittman 1992), FZI* (Mirzaei-Paiaman et al. 2018), FZI (Amaefule et al. 1993) techniques in defining rock types in our samples using the following equations:

$\log r 35_{\text {Winland }}=0.732+0.588 \log K-0.864 \log \phi$

$\log r 35_{\text {Pittman }}=0.225+0.565 \log K-0.5230 . \log \phi$
$F Z I=\frac{0.0314 \sqrt{\frac{k}{\phi}}}{\frac{\phi}{1-\phi}}$

$\mathrm{FZI}^{*}=0.0314 \sqrt{\frac{k}{\phi}}$

where r35, FZI and FZI* are in micron and permeability $(\mathrm{k})$ and porosity $(\phi)$ are in $\mathrm{mD}$ and fraction, respectively. Moreover, we used Lucia's petrophysical classes according to the following equation (Lucia et al. 2001):

$\log k=A-B \log (R F N)+(C-D \log (R F N)) \times \log (\phi)$

where $\mathrm{A}=9.7982, \mathrm{~B}=12.0838, \mathrm{C}=8.6711, \mathrm{D}=8.2965$ and RFN is Rock Fabric Number. Lucia defined rock classes according to the RFN values. The coarser grained rocks have a lower rock fabric number (RFN) and finer grained rocks a higher RFN. It should be noted that in Lucia's rock typing method similar RFNs correspond to rocks of similar grain size not pore throat radii.

Finally, capillary pressure curves of defined rock types were used to model water saturation by implementing parameters fitting method.

\section{Results}

\section{Petrography}

Petrographic analysis of the Fahliyan Formation has resulted in the identification of six microfacies based on their allochems, textures and sedimentary environments. Facies characteristics of the studied samples are summarized in Table 1, and the representative photomicrographs are provided in Fig. 3. In terms of depositional setting, the studied interval was deposited in a homoclinal carbonate ramp represented by lagoon, shoal, algal mound and open marine facies (Table 1). The recognized depositional model is consistent with previous studies on this formation in the Zagros area (e.g. Adabi et al. 2010; Jamalian et al. 2011; Jamalian et al. 2014; Dehkar et al. 2018; Noori et al. 2019). According to the sedimentological log (Fig. 4) and petrophysical evaluation, this formation is substantially composed of limestone with some thin dolomitized intervals. As shown in Fig. 5, micritization, cementation, dolomitization, dissolution and compaction (chemical and mechanical) have been identified as the main diagenetic features of the studied intervals. 
Table 1 Summarized characteristics of depositional facies, defined in this study, in the Fahliyan Formation

\begin{tabular}{|c|c|c|c|c|c|}
\hline Facies code & Facies name & Textures & $\begin{array}{l}\text { Sedimentary environ- } \\
\text { ment }\end{array}$ & Diagenesis & Pore type \\
\hline MF-1 & $\begin{array}{l}\text { Green algae, foraminifer } \\
\text { mudstone/wackestone }\end{array}$ & Mudstone/wackestone & Lagoon & $\begin{array}{l}\text { Cementation and dis- } \\
\text { solution }\end{array}$ & $\begin{array}{l}\text { Microporosity and intra- } \\
\text { particle }\end{array}$ \\
\hline MF-2 & $\begin{array}{l}\text { Bioclast, peloid pack- } \\
\text { stone/grainstone }\end{array}$ & Packstone/grainstone & Leeward shoal & $\begin{array}{l}\text { Cementation, dissolu- } \\
\text { tion and micritization }\end{array}$ & Interparticle and mouldic \\
\hline MF-3 & $\begin{array}{l}\text { Bioclast, ooid grain- } \\
\text { stone }\end{array}$ & Grainstone & Shoal & $\begin{array}{l}\text { Cementation, dissolu- } \\
\text { tion and compaction }\end{array}$ & Interparticle \\
\hline MF-4 & $\begin{array}{l}\text { Oncoid, bioclast grain- } \\
\text { stone/rudstone }\end{array}$ & Grainstone/rudstone & Seaward shoal & $\begin{array}{l}\text { Cementation, dissolu- } \\
\text { tion and micritization }\end{array}$ & Interparticle and mouldic \\
\hline MF-5 & $\begin{array}{l}\text { Lithocodium-algal } \\
\text { floatstone/rudstone / } \\
\text { boundstone }\end{array}$ & $\begin{array}{l}\text { Floatstone/rudstone/ } \\
\text { boundstone }\end{array}$ & Carbonate build-up & $\begin{array}{l}\text { Dissolution, dolomitiza- } \\
\text { tion and cementation }\end{array}$ & $\begin{array}{l}\text { Intraparticle, growth } \\
\text { framework and vuggy }\end{array}$ \\
\hline MF-6 & $\begin{array}{l}\text { Echinoderm wacke- } \\
\text { stone/packstone }\end{array}$ & Wackestone/packstone & Open marine & $\begin{array}{l}\text { Cementation, compac- } \\
\text { tion and dissolution }\end{array}$ & Vuggy \\
\hline
\end{tabular}

Considering facies characteristics, the LF and MF members are mainly consisting of grain-dominated facies with low mud content representing deposition under high-energy condition in shoal setting or algal facies with high values of porosity and permeability (Fig. 4). The sedimentary texture in these intervals varies from packstone to rudstone and floatstone.

In the MF, dominant pore types are interparticle, intercrystalline, intraparticle and mouldic. In the LF, in addition to all abovementioned pore types, dissolution moulds and vugs are frequently recorded that resulted in porosity and permeability enhancement (Fig. 4). Dissolution mainly occurred in shoal facies and led to enlargement of primary pores. However, calcite cementation occluded pore spaces and pore throats and negatively affected the reservoir quality in the studied succession.

The UF member has mainly composed of mud-dominated facies deposited in lagoon setting. In the lower parts, this member includes moderately sorted peloidal packstone with relatively high porosity, which are strongly influenced by calcite cementation (Fig. 4). Toward the upper parts, mudstone becomes the dominant texture. Some mouldic and intercrystalline pores are defined in this part of the formation.

\section{Rock typing}

Rock typing in hydrocarbon-bearing intervals, mainly carbonate rocks, has always been a challenging task for geoscientists and engineers. Lack of a universal approach for reservoir rock typing has impelled many researchers to introduce different methods (Kolodzie Jr et al. 1980; Pittman 1992; Lucia et al. 2001; Rezaee et al. 2006; Mirzaei-Paiaman et al.
2015, 2018). Moreover, data limitation and more importantly heterogeneous nature of carbonate reservoir in each hydrocarbon field impose much more difficulties in implementing these standard methods (Kadkhodaie-Ilkhchi et al. 2018; Al-Jawad et al. 2020). Carbonate reservoir rock types are generally complex to identify due to their formation process and sensitivity to diagenesis. Diagenetic processes such as cementation, dissolution, fracturing, dolomitization influence pore structure in carbonate rocks and increase pore network complexity and heterogeneity. As mentioned in the previous section, couple imprint of sedimentary environment and diagenetic processes in the studied formation have caused various pore types and considerable fluctuation of petrophysical properties. In the studied interval, porosity varies from less $1 \%$ to more than $26 \%$ and permeability ranges from $0.01 \mathrm{mD}$ to more than $2000 \mathrm{mD}$. Figure 6 shows the cross-plots of porosity versus permeability and the Lorenz plots for horizontal and vertical plug samples. As it can be seen from this figure, the Lorenz coefficients, as an index of reservoir heterogeneity, are equal to 0.89 for horizontal samples and 0.82 for vertical plugs. This index can vary from zero in a homogeneous reservoir to a maximum value of 1 (Tiab et al. 2015; Mirzaei-Paiaman et al. 2019).

In order to find best rock typing method in this reservoir, we compare the results of FZI, r35Pittman, r35Winland, FZI* and Lucia techniques in defining petrophysical rock types in our samples. However, prior to any calculation, in order to exclude erroneous values, a cut-off was applied on the data to define nonreservoir intervals with very low porosity $(<3 \%)$ and permeability $(<0.01 \mathrm{mD})$ (Tiab et al. 2015; Mehrabi et al. 2019). Note that these very low Poro-Perm zones are classified as RT1 in this study. Different methods such as histograms, discrete rock 

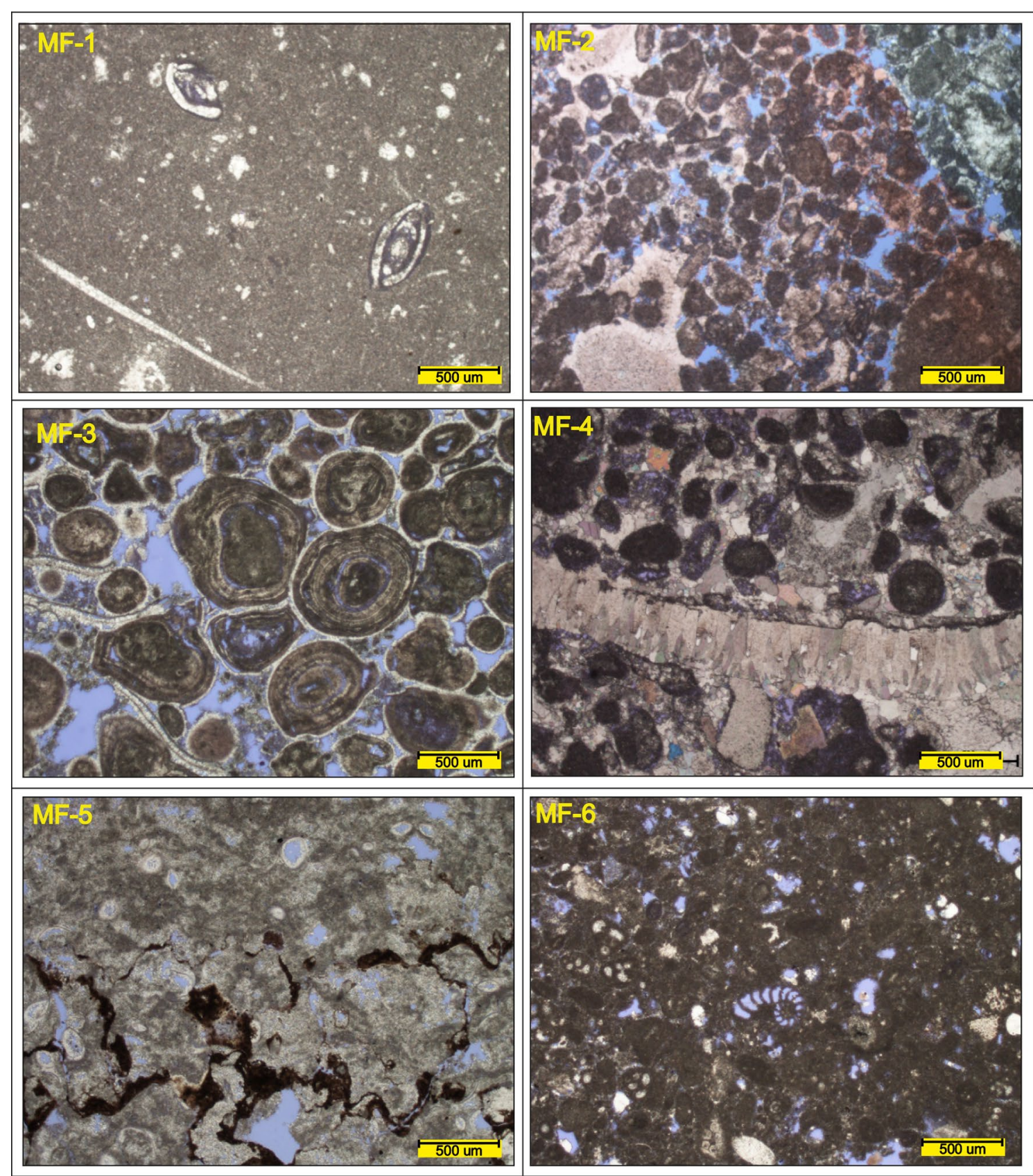

Fig. 3 Photomicrographs of depositional facies of the Fahliyan Formation in the study area. (MF-1=green algae, foraminifer mudstone/wackestone, MF-2 = bioclast, peloid packstone/grainstone,

typing (DRT), probability plots, global hydraulic element (GHE), test of normality and error analysis are used to find the optimum number of rock types in a reservoir (Abbaszadeh et al. 1996; Corbett et al. 2004; Tiab et al. 2015). In this study, DRT method was used because of its simplicity (Abbaszadeh et al. 1996; Mirzaei-Paiaman et al. 2018).
MF-3 = bioclast, ooid grainstone, MF-4 = oncoid, bioclast grainstone/ rudstone, MF-5 = lithocodium-algal floatstone/rudstone /boundstone, MF-6=echinoderm wackestone/packstone)

DRTno. $=$ Round $(\log$ index $)+A ; 0)$

where $\mathrm{A}$ is a constant and should be adjusted for each index (i.e. FZI, Winland and Pittman's r35 and FZI*) in order to have the outcomes starting from 1 . Including the rock type representing nonreservoir intervals with very low porosity 


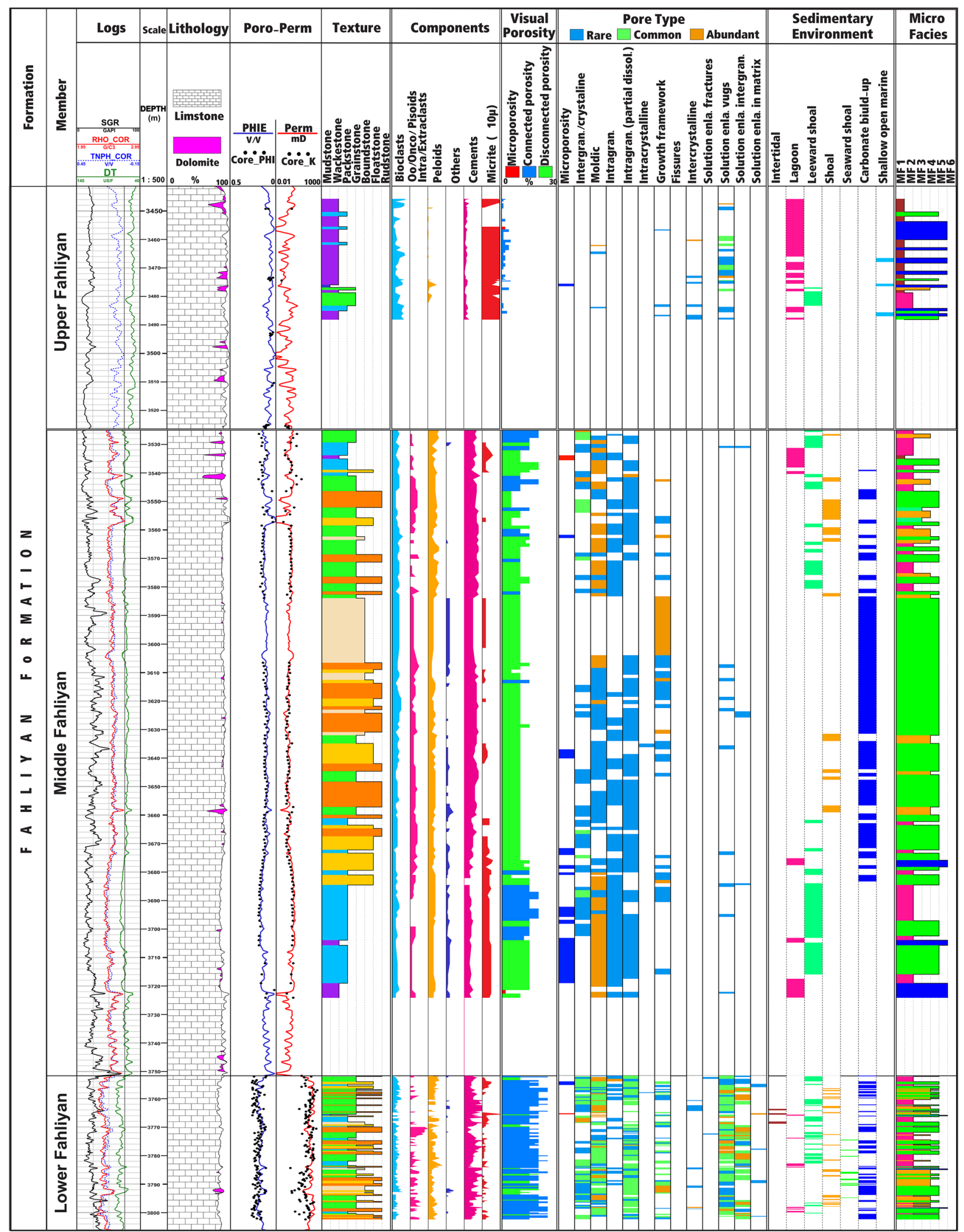

Fig. 4 Sedimentological log of the Fahliyan Formation in the studied field. Depositional facies, textures and settings along with important pore types are illustrated 
$(<3 \%)$ and permeability $(<0.01 \mathrm{mD})$, using A equal to 2 , 2.3, 2.9 and 3.2 for FZI, r35 Winland, r35 Pittman and FZI*, respectively, our data were classified into four rock types. Furthermore, we used Lucia's petrophysical rock types which classify our data into six rock types (Fig. 7).

In this study, MICP curves and pore throat radius distributions were used in order to evaluate the ability of abovementioned indices. Figure 7 shows the results of applying mentioned indices on our data. As it can be seen from this figure, while capillary pressure curves are not following similar trends, FZI cannot differentiate among them. On the other hand, it is expected that each rock type must have similar pore throat size distributions (Mirzaei-Paiaman et al. 2015, 2018). But this index classifies samples with completely different pore throat radii into same rock types. Also, implementing Lucia's petrophysical classes on our MICP data was not a good idea and this method's efficiency in separating samples into distinct groups is questionable (Fig. 7). Using r35winland and r35 Pittman, studied samples were classified into four rock types. Results show that both indices behave in relatively similar way and better than previously mention FZI and Lucia's methods (Fig. 7). Outcomes show that FZI* performed better than other indices to separate any existing rock types (Fig. 7). This method not only does find more distinct pore throat clusters than other techniques but also groups MICP curves in much more efficient way (Fig. 7). It should be noted that Mirzaei-Paiaman et al. 2015 and 2019 introduced FZI* method and verified it using 34 and $10 \mathrm{MICP}$ samples, respectively. Therefore, the present study which include 211 primary drainage mercury injection capillary pressure data can be considered as a comprehensive study in verification of this valuable newly developed method in defining petrophysical rock types.

\section{Pore facies (MICP)}

Pore facies analysis is a practical approach for the reservoir rock typing according to the pore geometry characteristics (Chehrazi et al. 2011; Aliakbardoust et al. 2013). Pore system characterization plays an important role in hydrocarbon reservoir studies because it controls fluid saturation and the reservoir rock quality (Rahimpour-Bonab et al. 2014). Analysis of pore size distribution allows reservoir characterization to be pore system oriented, and therefore, the defined reservoir models will be based on the pore system characteristics (Chehrazi et al. 2011). The mercury injection capillary pressure (MICP) curves are popular tools for pore size distribution characterization in reservoir rocks and have been widely used in numerous case studies (Purcell et al. 1949; Dullien et al. 1974; Schowalter 1979; Hollis et al. 2010; Chehrazi et al. 2011; Skalinski et al. 2013; Xu et al. 2013; Rahimpour-Bonab et al. 2014). In this study, MICP curves were used to classify the carbonate reservoir rock samples based on their pore size distribution characteristics.

\section{Pore facies 1}

This rock type is entirely composed of lime mudstone and wackestone with no or very rare macroscopic pores. Almost all pores and microfractures are completely filled with sparry calcite cement (Fig. 8). It shows very low porosity (less than 3\%) and permeability (less than $0.01 \mathrm{mD}$ ). Figure 8 illustrates an example of thin section image of this rock type and pore throat size distribution (PTSD) for all samples categorized in this class. As it can be seen from this figure, pores are in nanoscale with throat radius smaller than 0.1 micron, this increase entry pressure of this rock type to more than 2000 psi. This rock type mostly belongs to the upper parts of UF member.

\section{Pore facies 2}

This rock type has a grain-supported texture that is composed of fine (100-150 microns) peloids and ooids as dominant allochems (Fig. 8). Grains are well-rounded, often spherical and mostly very well sorted. Cementation is major diagenetic process in this rock type, occurring as pore-filling cements. Interparticle porosity was considerably occluded by calcite cements. Remaining porosity is because of the isolated moulds with poor connectivity and, consequently, low permeability. Average porosity and permeability are $12 \%$ and $0.4 \mathrm{mD}$, respectively. In this rock type, dominant pore throat sizes are between 0.1 and 0.5 microns which can classify as micropores. Average entry pressure is 500 psi (Fig. 8). It mainly belongs to the UF and MF members.

\section{Pore facies 3}

It represents grain-supported facies, containing fine (150-250 microns) peloids and ooids, as dominant allochems. Grains are well-rounded, often spherical and mostly very well-sorted. Calcite cementation and compaction are two important diagenetic processes in this rock type (Fig. 8). These has reduced pore throats and, consequently, permeability to some extent. Average porosity and permeability are $20 \%$ and $55 \mathrm{mD}$, respectively. Dominant PTS is between $0.1-2$ microns. The entry pressure is below $250 \mathrm{psi}$ 

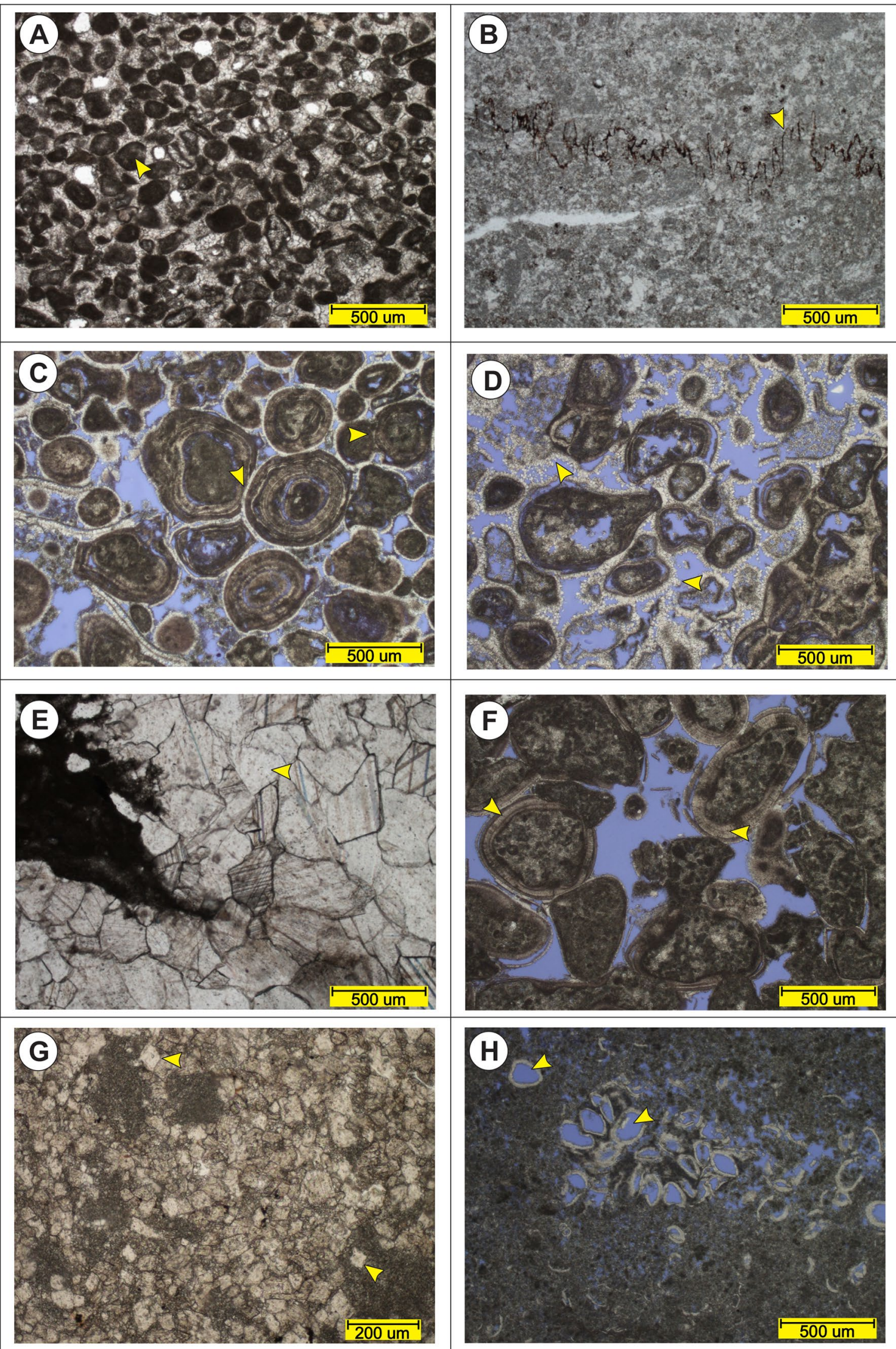
4Fig. 5 Main diagenetic features influencing reservoir quality of the Fahliyan Formation. (a) micritization, (b) chemical compaction, (c) mechanical compaction, (d, e and $\mathbf{f})$ cementation (g) dolomitization and (h) dissolution

(Fig. 8). This rock type shows limited distribution and can be detected mostly in the MF member.

\section{Pore facies 4}

This rock type is composed of coarse intraclasts grainstone, with large mollusk debris (Fig. 8). Equant calcite cement is main diagenetic feature in this rock type. Porosity and permeability are generally high; porosity values range from 11 to $26 \%$ and permeability values vary from 129 to 2100 $\mathrm{mD}$. These high values of porosity and permeability result from the extensive dissolution. Pores dominantly macro-/ megapores and their throat radius range between 1 and 100 microns. However, different PTS are recorded indicating a poor sorting. Large pores with wide pore throat radii cause very low entry pressure (lower than $10 \mathrm{psi}$ ) and flat PC curves. This rock type mainly belongs to the LF member.

\section{Saturation height modelling}

Capillary pressure (PC) data are crucial in reservoir characterization and distribution during static and dynamic modelling (Tiab et al. 2015; Al-Bulushi et al. 2019). Capillary pressure curve tends to be more complex in carbonates in comparison with the siliciclastic reservoirs (Cuddy et al. 1993; Al Waili 2009; Chudi et al. 2010). Therefore, accurate determination of this property is essential in carbonate reservoirs characterization (Ahr 2011). There are a series of corrections including closure, stress, clay content and fluid corrections which should be applied on laboratory capillary pressure curves before fitting the capillary curves by the saturation height functions (Honarpour et al. 2004; McPhee et al. 2015; Lian et al. 2016; Kundu et al. 2017; Al-Bulushi et al. 2019). In this study, all PC curves are corrected for closure effect. Clay content and stress corrections were not applied because of clean (clay-free) limestone lithology of the Fahliyan Formation and laboratory test under reservoir P-T condition (Lian et al. 2016; Hulea et al. 2018). The last correction is wettability and interfacial tension correction. Because of the difference in wettability and surface tension between laboratory and reservoir fluid system, it is necessary to convert laboratory-derived PC data into reservoir PC (Lian et al. 2016; Kundu et al. 2017).
Numerous saturation functions are being used to describe the link between water saturation and capillary pressure (Leverett 1941; Wright et al. 1955; Aufricht et al. 1957; Heseldin 1974a, b; Johnson 1987a, b; Alger et al. 1989; Sondena 1992; Cuddy et al. 1993; Skelt et al. 1995a, b; Harrison et al. 2001). Researchers use these functions and reservoir properties to calculate more precise water saturation and initial hydrocarbon in place (Jamiolahmady et al. 2007; Kamalyar et al. 2012; Adams 2016; Lian et al. 2016; Kundu et al. 2017).

In this study, we used determined pore types as a basis to estimate water saturation. In order to decrease the uncertainty coming from permeability prediction and subsequent rock typing in uncored wells, parameters fitting approach were applied on capillary pressure curves. Defined pore facies were used to average MICP samples to have a representative capillary pressure curve for each pore facies. Then, we used Eq. (7) to extract fitting parameters in each pore facies as follows (Skelt et al. 1995):

$\log (S W)=M * \log (P C)+C$

where PC is the capillary pressure in PSI, SW is water saturation in fraction and $\mathrm{M}$ and $\mathrm{C}$ are constant and curve fitting parameters. Using this equation, best fit values of the $\mathrm{M}$ and $\mathrm{C}$ parameters were determined for capillary pressure curves. Finally, relationship between core porosity and these parameters were investigated. Figure 9 represents relationship between fitting parameters and core porosity.

Substituting extracted correlations in Eq. (7) allows creating a model as a function of two variables: the capillary pressure (PC) or height above free water level (HAFWL) and the core porosity as follows:

$$
\begin{aligned}
\log (S W)= & (-0.07+0.38 * \log (\text { porosity })) * \log (P C) \\
& +(-1.22-3.74 * \log (\text { porosity }))
\end{aligned}
$$

As porosity is the most straightforward parameter to be calculated from petrophysical curves with low uncertainty, it can be utilized in Eq. (8) to calculate water saturation in well and reservoir scale. This equation, in fact, belongs to a surface that describes the relationship between irreducible water saturation, core porosity and height above free water level in a 3D space. Figure 10 shows the model surface in relation to the capillary pressure curve for each pore type. Using equation of this surface, water saturation can be calculated at any point above free water level by porosity values derived from petrophysical curves.

In order to investigate the accuracy of the model, calculated water saturation was compared with log-derived water saturation in five of the oldest drilled wells and their

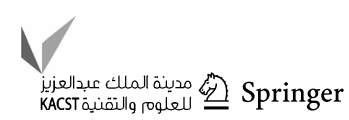


petrophysical logs had not experienced production in the studied field (Fig. 11). As it can be seen in Fig. 11, there is a high consistency between the results. Figure 12 represents histogram of difference between log-derived water saturation and saturation height function-calculated initial water saturation in some of the oldest drilled wells in the studied field. It shows that error of calculation is dominantly very low and varies between $\mp 20$ percent, with the highest frequency close to zero. Therefore, 3D model of water saturation can be, easily, built, based on the 3D model of porosity.

\section{Discussion}

In this study, sedimentary environment and diagenetic processes of the Fahliyan Formation were investigated in an oil field in northwest of Persian Gulf. Pore types were analysed based on detailed petrographic studies. Results show a wide various types of pore spaces ranging from micropores plugged with calcite cement to interconnected megapores which make a precise rock typing necessary for any kind of study in this reservoir. Rock typing analysis was performed using different methods to find the parameters controlling the reservoir quality and introduce the best way for classification of reservoir rocks according to their pore facies characteristics. Four pore facies (PF) were identified according to the FZI* method. The pore size distribution and capillary pressure

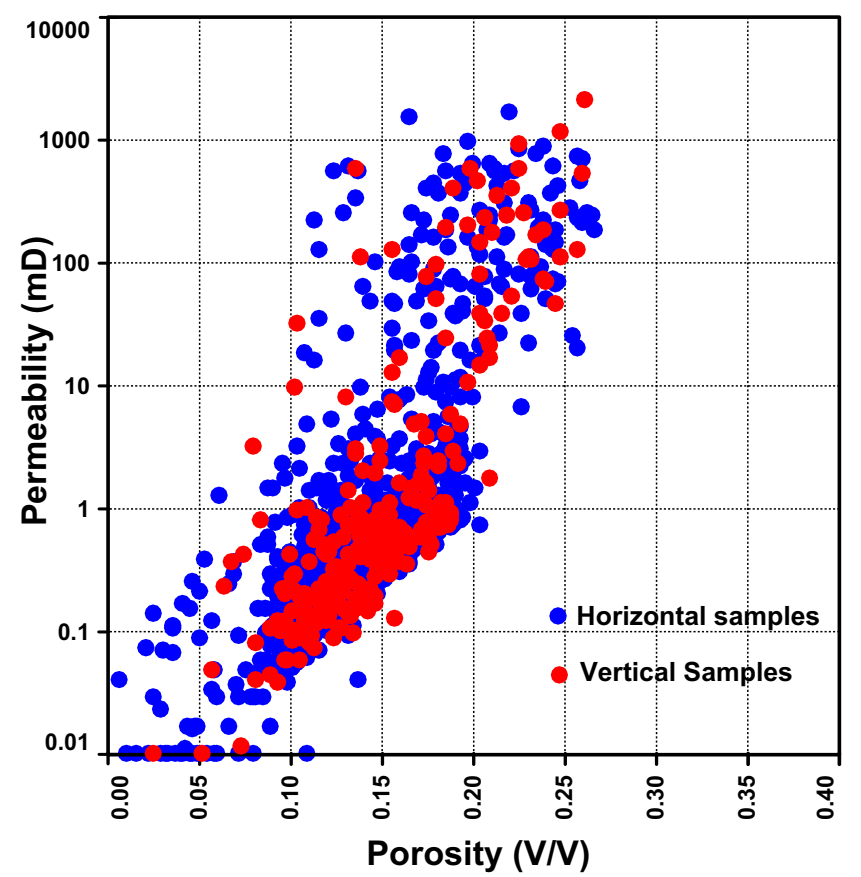

Fig. 7 Identification of petrophysical rock types using MICP curves and pore size distribution for studied samples by FZI, Lucia, r35 Winland, r35 Pittman and FZI* techniques

curve for each pore facies is unique, and each pore facies contains samples with the greatest similarities in MICP and PSD curves. Since water saturation is dependent on the pore type and pore facies, the extracted pore facies were used in order to define the water saturation in the studied field. Pore facies were used to model initial fluid saturation using definition of a saturation height function that is written based on HAFWL and porosity.

Generally, reservoir quality increases from PF1 to PF4. This is evident from thin section studies, pore throat size distribution and entry pressure values for each facies. According to the petrographic analysis and MICP curves, a decrease in irreducible water saturation and entry pressure and increase in pore throat size in capillary pressure-defined classes are compatible with increase in interparticle to mouldic and vuggy pores ratio and a general decrease in the intergranular and porefilling cements from PF1 to PF4.

The results show that the initial rock texture is important controlling factor on reservoir quality. In fact, deteriorating diagenetic overprints act mostly in low-quality textures like mud-dominated intervals. On the other hand, grain-supported textures mostly experienced reservoir quality enhancer events such as dissolution. For example, PF1, which is easily detectable with high entry

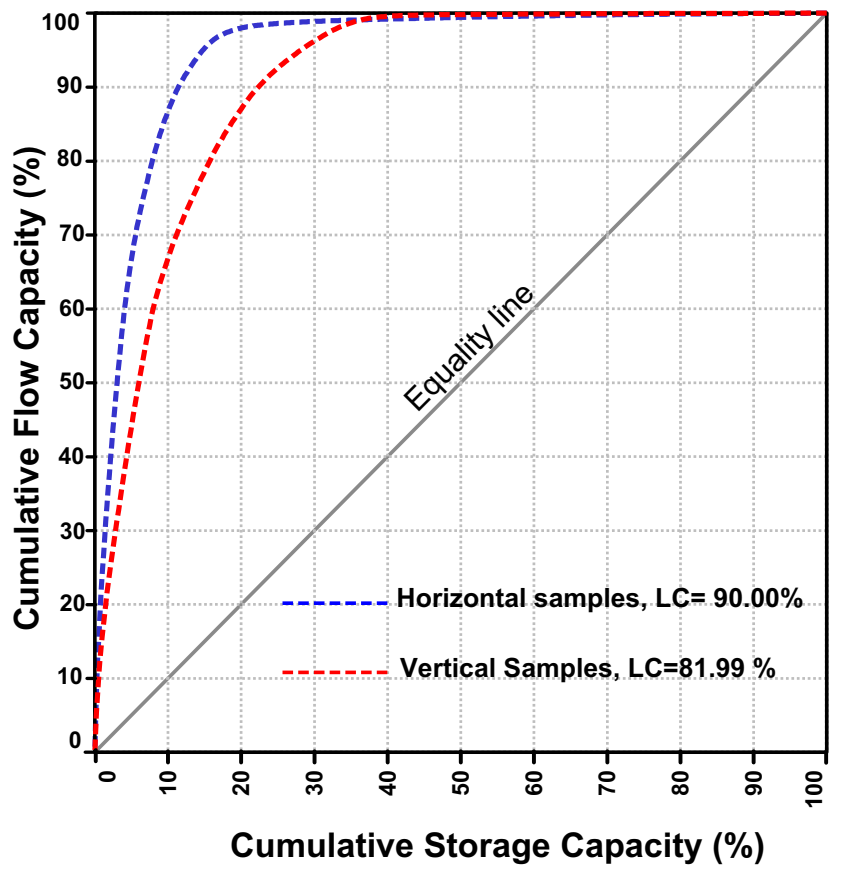

Fig. 6 a Cross-plot of porosity vs. permeability of horizontal and vertical plug samples and (b) pertinent Lorenz coefficient (LC) 

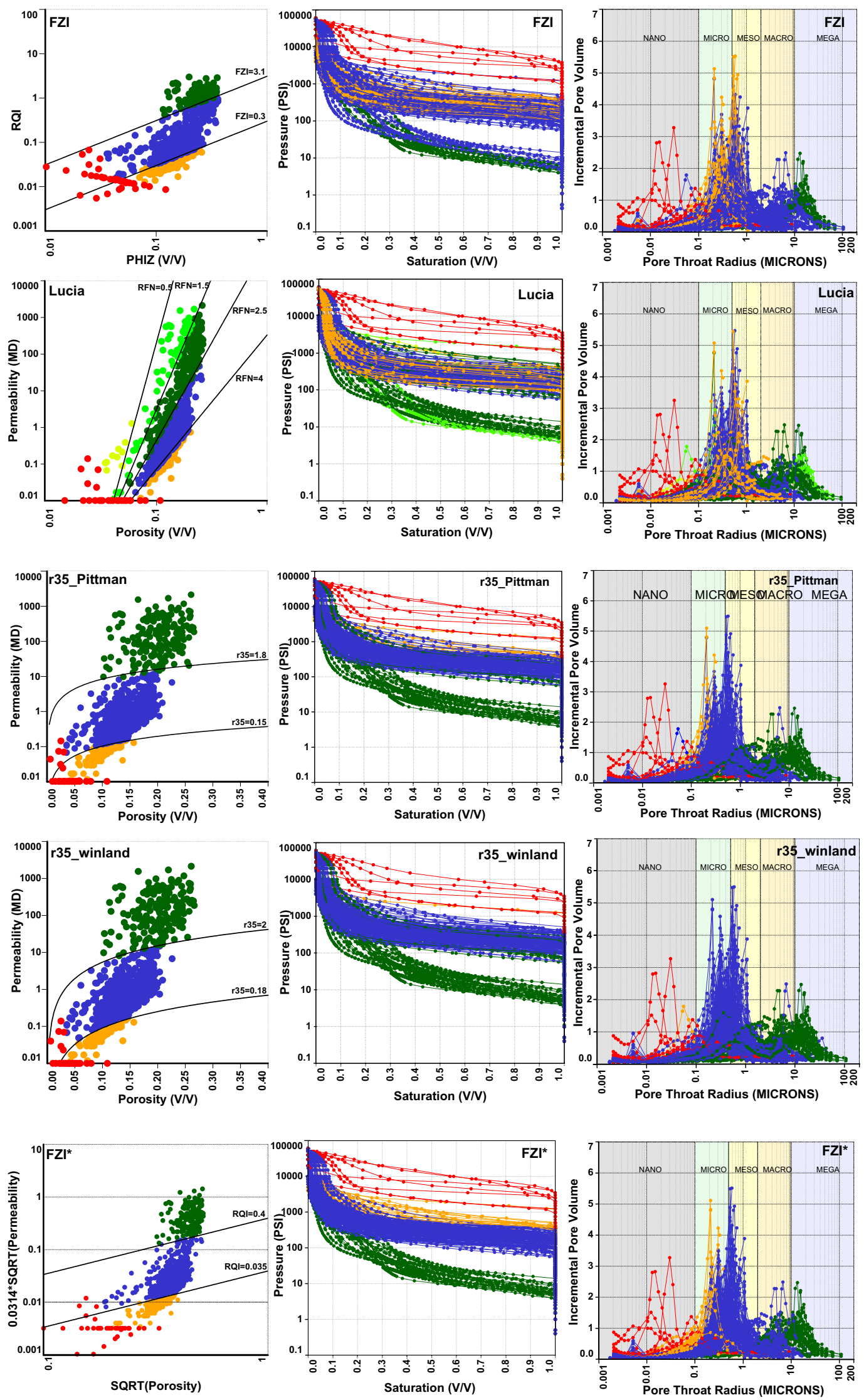

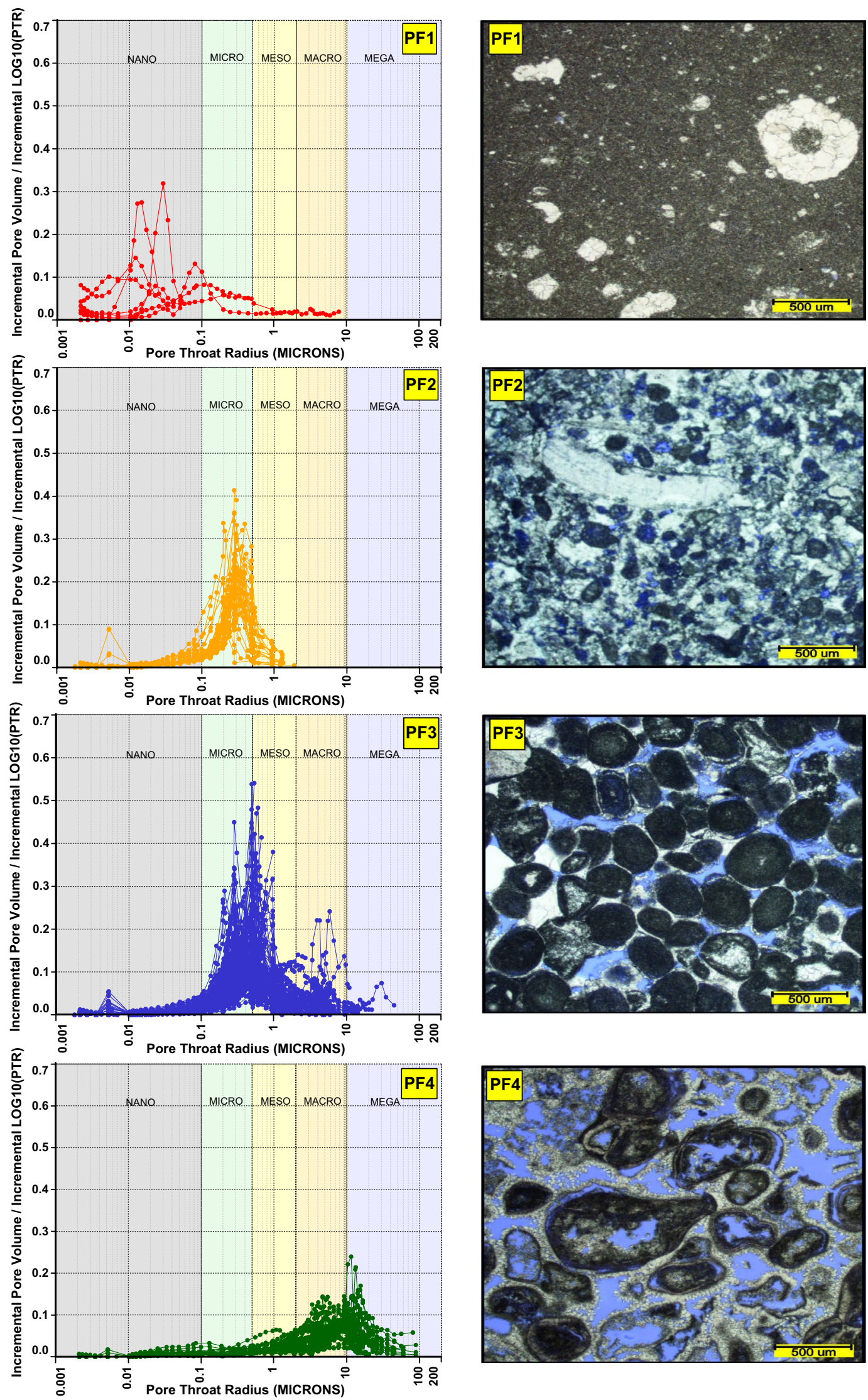

Fig. 8 (left) PTSD curves for pore facies and (right) an example thin section micrograph for identified pore types

$\sqrt{ }$

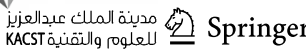



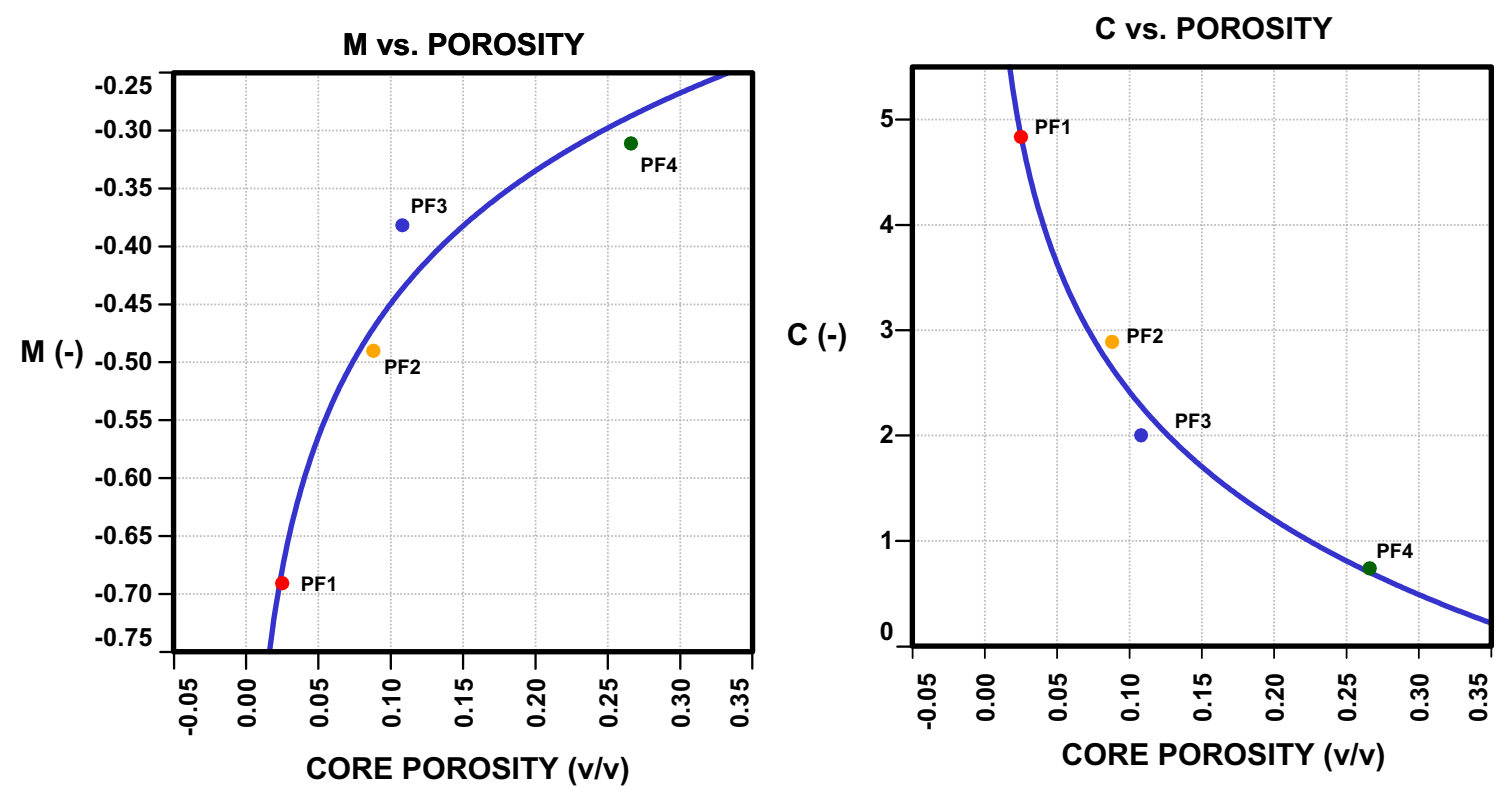

Fig. 9 Correlation between porosity and fitting parameters in pore facies framework

Fig. 10 Visualization of the 3D model surface in relation to the capillary pressure for each pore type

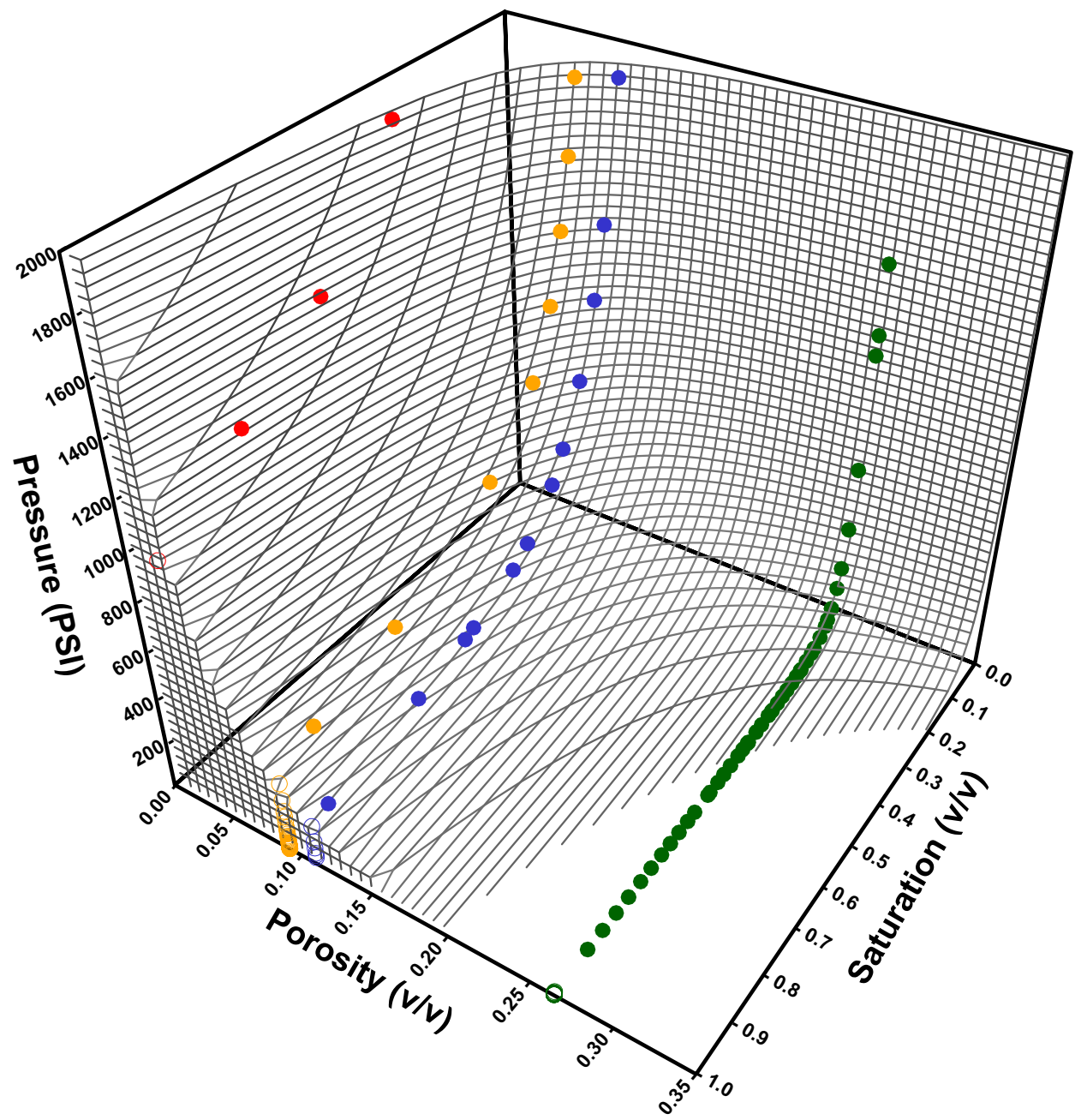

Springer 


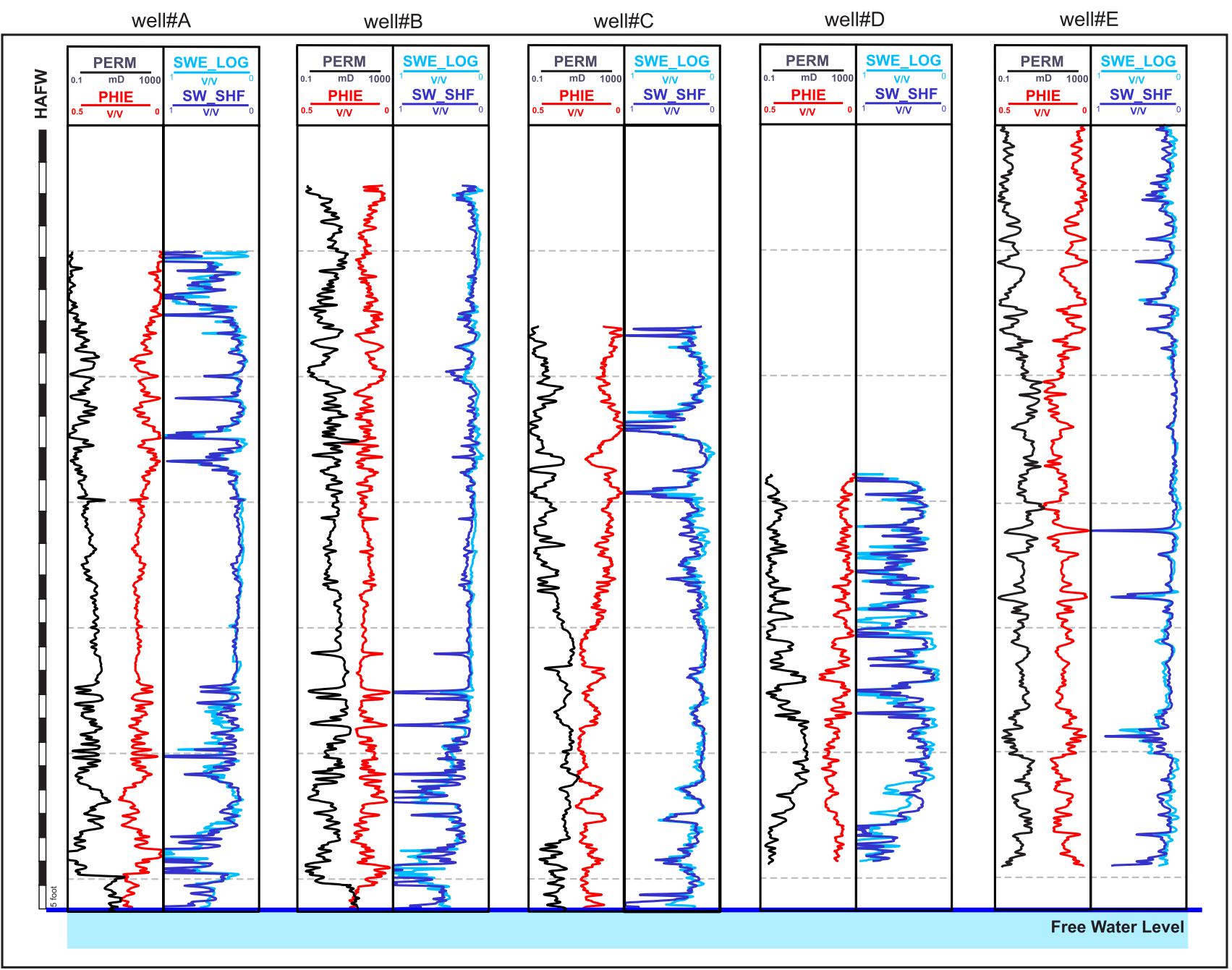

Fig. 11 Comparison between the calculated water saturation using petrophysical logs- and saturation height function-derived water saturation in five of the oldest wells drilled in the studied field

pressure, belongs to the lagoon environment. In this facies, pore types are dominantly nanopores and larger pores are fully filled by calcite cements. On the contrary, PF4 shows the best reservoir quality in the Fahliyan Formation. This is because of the coarse grain-supported textures and dominant interparticle pores, and extensive dissolution created a connected pore network with various pore throat sizes. The frequency of pore-filling cements decreases from PF1 to PF4. However, isopachous calcite cement is common only in PF4.

Pore throat radius changes from nanoscale to megascale from PF1 to PF4. PF1 is limited to the UF member. Formation in the low-energy environment and subsequent cementation in large pore spaces caused low porosity and high percentage of irreducible water saturation intervals in upper parts of Fahliyan Formation. An increase in pore throat radius size to microand mesopores in PF2 and PF3, respectively, resulted in decline in irreducible water saturation and entry pressure rather than PF1. In spite of the preserved porosity, permeability reduced in PF3 due to the diagenetic processes, mainly physical compaction and cementation. PF4 with macro- to megapores is the most frequent facies in LF member. Interconnected pore spaces resulted from dissolution, enhancing the porosity and permeability, created the best reservoir intervals in LF member with flat MICP curves and low irreducible water saturation.

As permeability prediction and subsequent rock typing in uncored wells are challenging tasks in reservoir studies, most specifically in heterogeneous carbonate reservoirs, relationship between pore types and irreducible water saturation was used to model water initial saturation in the pore facies framework. Generally, from PF-1 to PF4 irreducible water saturation decreases, while pore types change from isolated pores to completely interconnected pore spaces with the highest reservoir quality. 
Fig. 12 Histogram of difference between saturation height function-derived and logderived water saturation in the first drilled wells in the studied field. Colours represent different wells

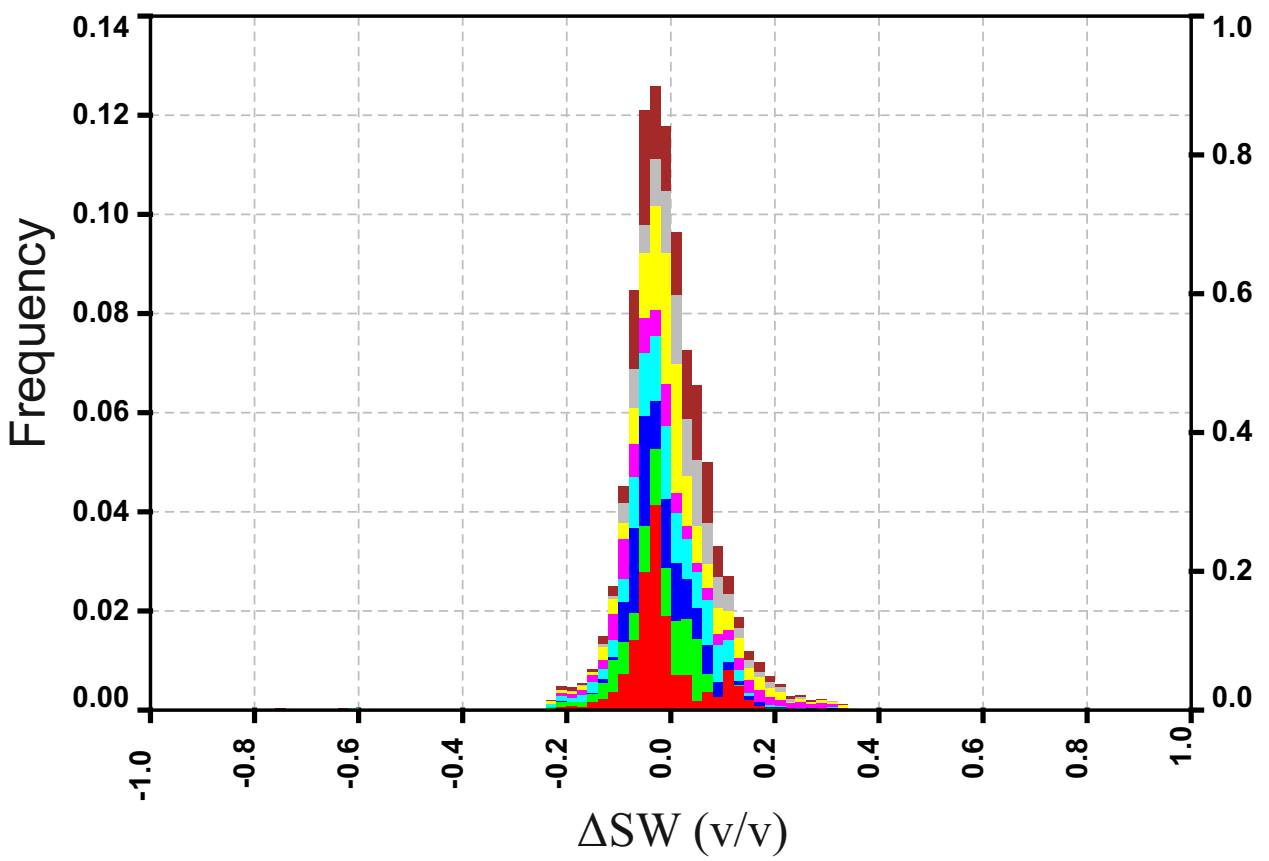

Results show that a there is a logarithmic correlation between porosity and fitting parameters that can be utilized to generate a formula to model water saturation. From PF-1 to PF-4, M values increase, while $\mathrm{C}$ decreases from PF-1 to PF-4. Results show that extracted relationship between porosity and fitting parameters in core scale can be used to model water saturation in well or reservoir scale using log-derived porosity.

\section{Summary and conclusions}

In this study, different types of information including thin sections, routine and special core analysis results were integrated to categorize reservoir intervals of the Fahliyan Formation into specific rock types and model the initial water saturation in the framework of pore facies. The following conclusions were obtained through application and consideration of facies studies, diagenesis, reservoir properties and MICP assessments.

- According to the core and thin-section petrographic studies, six facies were recognized in the Fahliyan Formation. Mudstone to wackestone facies deposited in lagoonal settings have the lowest reservoir quality. The main pore types in these intervals are microporosity and interparticle. On the other hand, facies with grainstone to rudstone textures deposited in shoal environment have best reservoir quality formed by dominant interparticle and vuggy pores.
- Petrophysical rock types were defined by implementing different rock typing indices on primary drainage capillary pressure data. In this way, four petrophysical rock types were recognized based on pore size distribution and capillary pressure curves trends. FZI* method is the best way to separate data set into discrete groups in the way that each class represents unique pore geometry and capillary pressure curve (pore facies).

- The identified pore facies were used as basis for water saturation modelling. Porosity as the straightforward reservoir properties to model was used to model water saturation.

Acknowledgments The authors wish to thank the NIOC for the data preparation and permission to publish the data. The authors are also grateful to Turgay Ertekin, Editor-in-Chief of Journal of Petroleum Exploration and Production Technology, for editorial handling and three anonymous reviewers of this article for their time and constructive comments.

\section{Declaration}

Conflict of interest On behalf of all the co-authors, the corresponding author states that there is no conflict of interest.

Funding No funding.

Open Access This article is licensed under a Creative Commons Attribution 4.0 International License, which permits use, sharing, adaptation, distribution and reproduction in any medium or format, as long as you give appropriate credit to the original author(s) and the source, 
provide a link to the Creative Commons licence, and indicate if changes were made. The images or other third party material in this article are included in the article's Creative Commons licence, unless indicated otherwise in a credit line to the material. If material is not included in the article's Creative Commons licence and your intended use is not permitted by statutory regulation or exceeds the permitted use, you will need to obtain permission directly from the copyright holder. To view a copy of this licence, visit http://creativecommons.org/licenses/by/4.0/.

\section{References}

Abbaszadeh M, Fujii H, Fujimoto F et al (1996) Permeability prediction by hydraulic flow units-theory and applications. SPE Form Eval 11:263-271

Adabi MH, Salehi MA, Ghabeishavi A (2010) Depositional environment, sequence stratigraphy and geochemistry of Lower Cretaceous carbonates (Fahliyan Formation), south-west Iran. J Asian Earth Sci 39:148-160

Adams SJ (2016) Which Saturation-Height Function? In: SPWLA 57th Annual Logging Symposium

Ahr WM (2011) Geology of carbonate reservoirs: the identification, description and characterization of hydrocarbon reservoirs in carbonate rocks. John Wiley \& Sons

Al-Bulushi N, Kraishan G, Hursan G, others (2019) Capillary Pressure Corrections, Quality Control and Curve Fitting Workflow. In: International Petroleum Technology Conference

Al-Jawad SNA, Abd Ahmed M, Saleh AH (2020) Integrated reservoir characterization and quality analysis of the carbonate rock types, case study, southern Iraq. Journal of Petroleum Exploration and Production Technology 10:3157-3177

Al-Khaldi NA, Khamatdinov RA, Al-Otaibi MH, et al (2012) Water Saturation Modeling in Khafji Carbonate Reservoir. In: Abu Dhabi International Petroleum Conference and Exhibition

Al Waili IH (2009) Developing generalised capillary pressure curves and saturation height function for Shuaiba carbonate reservoirs in field A. In: SPE Annual Technical Conference and Exhibition

Alger RP, Luffel DL, Truman RB et al (1989) New unified method of integrating core capillary pressure data with well logs. SPE Form Eval 4:145-152

Aliakbardoust E, Rahimpour-Bonab H (2013) Effects of pore geometry and rock properties on water saturation of a carbonate reservoir. J Petrol Sci Eng 112:296-309

Amaefule JO, Altunbay M, Tiab D, et al (1993) Enhanced reservoir description: using core and log data to identify hydraulic (flow) units and predict permeability in uncored intervals/wells. In: SPE annual technical conference and exhibition

Askari AA, Behrouz T (2011) A fully integrated method for dynamic rock type characterization development in one of iranian offshore oil reservoir. Journal of chemical and petroleum engineering 45:83-96

Aufricht WR, Koepf EH et al (1957) The interpretation of capillary pressure data from carbonate reservoirs. J Petrol Technol 9:53-56

Cannon S (2015) Petrophysics: a practical guide. John Wiley \& Sons

Chehrazi A, Rezaee R, Rahimpour H (2011) Pore-facies as a tool for incorporation of small-scale dynamic information in integrated reservoir studies. J Geophys Eng 8:202-224

Chudi O, Simon R, Omobude OA, others (2010) Saturation Modelling in a Geological Complex Clastic Reservoir Using Log Derived Saturation Height Function: A Case Study of the E2 Reservoir, Era Eko Field in the Niger Delta. In: Nigeria Annual International Conference and Exhibition
Corbett PWM, Potter DK (2004) Petrotyping: A basemap and atlas for navigating through permeability and porosity data for reservoir comparison and permeability prediction. In: Paper SCA2004-30 presented at the International Symposium of the Society of Core Analysts

Cuddy S, Allinson G, Steele R, others (1993) A simple, convincing model for calculating water saturations in Southern North Sea gas fields. In: SPWLA 34th annual logging symposium

Dakhelpour-Ghoveifel J, Shegeftfard M, Dejam M (2019) Capillarybased method for rock typing in transition zone of carbonate reservoirs. Journal of Petroleum Exploration and Production Technology 9:2009-2018

Dehkar A, Sajjadian VA, Noora MR, Shabani Goorji K (2018) Microfacies analysis and depositional environment of the Fahliyan Formation (Lower Cretaceus), Abadan plain, West South of Iran (Arvand-field). Scientific Quaterly Journal of Geoscience. 27:45-52

Dullien FAL, Dhawan GK (1974) Characterization of pore structure by a combination of quantitative photomicrography and mercury porosimetry. J Colloid Interface Sci 47:337-349

Embry AF, Klovan JE (1971) A late Devonian reef tract on northeastern Banks Island, NWT. Bull Can Pet Geol 19:730-781

Esther, Cui (2015) Initial Water Saturation Calculation through Integrated Methods for 3D Unconventional Reservoir Modeling. In: SPE Kuwait Oil and Gas Show and Conference

Flügel E (2013) Microfacies of carbonate rocks: analysis, interpretation and application. Springer Science \& Business Media

Ghazban F (2007) Petroleum geology of the Persian Gulf. Joint publication

Ghedan SG, Thiebot BM, Boyd DA (2004) Modeling and Validation of Initial Water Saturation in the Transition Zone of Carbonate Oil Reservoirs. In: Abu Dhabi International Conference and Exhibition

Harrison B, Jing XD, others (2001) Saturation height methods and their impact on volumetric hydrocarbon in place estimates. In: SPE Annual Technical Conference and Exhibition

Heseldin GM (1974) A method of averaging capillary pressure curves. In: SPWLA 15th Annual Logging Symposium

Heseldin GM, others (1974) A method of averaging capillary pressure curves. In: SPWLA 15th Annual Logging Symposium

Hollis C, Vahrenkamp V, Tull S et al (2010) Pore system characterisation in heterogeneous carbonates: An alternative approach to widely-used rock-typing methodologies. Mar Pet Geol 27:772-793

Honarpour MM, Djabbarah NF, Kralik JG, others (2004) Expertbased methodology for primary drainage capillary pressure measurements and modeling. In: Abu Dhabi International Conference and Exhibition

Hulea IN et al (2018) Saturation-Height Modeling: Assessing Capillary Pressure Stress Corrections. Petrophysics 59:397-406

Jamalian M, Adabi MH (2014) Geochemistry, microfacies and diagenetic evidences for original aragonite mineralogy and open diagenetic system of Lower Cretaceous carbonates Fahliyan Formation (Kuh-e Siah area, Zagros Basin, South Iran). Carbonates Evaporites 30:77-98

Jamalian M, Adabi MH, Moussavi MR et al (2011) Facies characteristic and paleoenvironmental reconstruction of the Fahliyan Formation, Lower Cretaceous, in the Kuh-e Siah area, Zagros Basin, southern Iran. Facies 57:101-122

James GA, Wynd JG (1965) Stratigraphic nomenclature of Iranian oil consortium agreement area. AAPG Bull 49:2182-2245

Jamiolahmady M, Sohrabi MS, Tafat M (2007) Estimation of saturation height function using capillary pressure by different approaches. In: SPE Europec/69th EAGE Conference and Exhibition. p SPE--107142 
Johnson A (1987) Permeability averaged capillary data: a supplement to $\log$ analysis in field studies. In: SPWLA 28th Annual Logging Symposium

Johnson A, others (1987) Permeability averaged capillary data: a supplement to log analysis in field studies. In: SPWLA 28th Annual Logging Symposium

Kadkhodaie-Ilkhchi A, Kadkhodaie-Ilkhchi R (2018) A Review of Reservoir Rock Typing Methods in Carbonate Reservoirs: Relation between Geological, Seismic and Reservoir Rock Types. Iranian Journal of Oil \& Gas Science and Technology 7:13-35

Kamalyar K, Mesbah M, Jamialahmadi M (2013) An investigation of using different saturation height functions by introducing rock type property. Energy Sources, Part A: Recovery, Utilization and Environmental Effects 35:495-509

Kamalyar K, Sheikhi Y, Jamialahmadi M (2012) An Investigation of Using Different Saturation Height Functions in an Iranian Oil Reservoir. Pet Sci Technol 30:412-424

Kennedy M (2015) Practical petrophysics. Elsevier

Kolodzie Jr S, others (1980) Analysis of pore throat size and use of the Waxman-Smits equation to determine OOIP in Spindle Field, Colorado. In: SPE annual technical conference and exhibition

Kumar R, Asset MH (2011) Development of saturation height functions for a multilayered carbonate reservoir of an Indian Offshore Field. In: The 9th Biennial international conference and exposition on petroleum geophysics, held at Hyderabad

Kundu A, Voleti DK, Rebelle M, et al (2017) Building Variable Saturation Height Functions with an Improved Rock Typing Scheme. In: Abu Dhabi International Petroleum Exhibition \& Conference

Lalicata J, Tanis EA, Reed DA, et al (2012) A Saturation Height Function Model Derived From Capillary Pressure, Lower Etchegoin/ Williamson Reservoir, Lost Hills Field. In: SPE Western Regional Meeting

Leverett M (1941) Capillary behavior in porous solids. Transactions of the AIME 142:152-169

Lian PQ, Tan XQ, Ma CY et al (2016) Saturation modeling in a carbonate reservoir using capillary pressure based saturation height function: a case study of the Svk reservoir in the Y Field. Journal of Petroleum Exploration and Production Technology 6:73-84

Lucia FJ (2007) Carbonate reservoir characterization: An integrated approach. Springer Science \& Business Media

Lucia FJ, Jennings JW Jr, Rahnis M, Meyer FO (2001) Permeability and rock fabric from wireline logs, Arab-D reservoir, Ghawar field, Saudi Arabia. GeoArabia 6:619-646

Ma YZ (2019) Quantitative geosciences: data analytics, geostatistics, reservoir characterization and modeling. Springer

McPhee C, Reed J, Zubizarreta I (2015) Core analysis: a best practice guide. Elsevier

Mehrabi H, Rahimpour-Bonab H, Hajikazemi E, Jamalian A (2015) Controls on depositional facies in Upper Cretaceous carbonate reservoirs in the Zagros area and the Persian Gulf. Iran Facies $61: 23$

Mehrabi H, Ranjbar-Karami R, Roshani-Nejad M (2019) Reservoir rock typing and zonation in sequence stratigraphic framework of the Cretaceous Dariyan Formation, Persian Gulf. Carbonates Evaporites 34:1833-1853. https://doi.org/10.1007/ s13146-019-00530-2

Mirzaei-Paiaman A, Ostadhassan M, Rezaee R et al (2018) A new approach in petrophysical rock typing. J Petrol Sci Eng 166:445-464

Mirzaei-Paiaman A, Sabbagh F, Ostadhassan M et al (2019) A further verification of FZI* and PSRTI: Newly developed petrophysical rock typing indices. J Petrol Sci Eng 175:693-705

Mirzaei-Paiaman A, Saboorian-Jooybari H (2016) A method based on spontaneous imbibition for characterization of pore structure: Application in pre-SCAL sample selection and rock typing. Journal of Natural Gas Science and Engineering 35:814-825
Mirzaei-Paiaman A, Saboorian-Jooybari H, Pourafshary P (2015) Improved method to identify hydraulic flow units for reservoir characterization. Energy Technology 3:726-733

Moore CH, Wade WJ (2013) Carbonate reservoirs: Porosity and diagenesis in a sequence stratigraphic framework. Newnes

Noori H, Mehrabi H, Rahimpour-Bonab H, Faghih A (2019) Tectonosedimentary controls on Lower Cretaceous carbonate platforms of the central Zagros, Iran: An example of rift-basin carbonate systems. Mar Pet Geol 110:91-111

Omeke JE, Ugwoke M, Aihumekeokhai BO, others (2014) A New Approach to Water Saturation Modeling and Distribution in Dynamic Models Using Log Derived Saturation Height Function (SHF)(A Case Study of Niger Delta Province). In: SPE Nigeria Annual International Conference and Exhibition

Pittman ED (1992) Relationship of porosity and permeability to various parameters derived from mercury injection-capillary pressure curves for sandstone. AAPG Bull 76:191-198

Purcell WR et al (1949) Capillary pressures-their measurement using mercury and the calculation of permeability therefrom. J Petrol Technol 1:39-48

Rahimpour-Bonab H, Aliakbardoust E (2014) Pore facies analysis: incorporation of rock properties into pore geometry based classes in a Permo-Triassic carbonate reservoir in the Persian Gulf. J Geophys Eng 11:35008

Rezaee MR, Jafari A, Kazemzadeh E (2006) Relationships between permeability, porosity and pore throat size in carbonate rocks using regression analysis and neural networks. J Geophys Eng 3:370-376

Schowalter TT (1979) Mechanics of secondary hydrocarbon migration and entrapment. AAPG Bull 63:723-760

Setudehnia A (1978) The mesozoic sequence in south-west Iran and adjacent areas. J Pet Geol 1:3-42

Skalinski M, Kenter J (2013) Pore typing workflow for complex carbonate systems. AAPG Annual

Skelt C, Harrison B (1995) An integrated approach to saturation height analysis. In: SPWLA 36th Annual Logging Symposium

Skelt C, Harrison B, others (1995) An integrated approach to saturation height analysis. In: SPWLA 36th Annual Logging Symposium

Sondena E (1992) An empirical method for evaluation of capillary pressure data. In: Proceedings of the Society of Core Analysts Third European Core Analysis Symposium. p p129

Tavoosi-Iraj P, Mehrabi H, Rahimpour-Bonab H, Ranjbar-Karami R (2021) Quantitative analysis of geological attributes for reservoir heterogeneity assessment in carbonate sequences; a case from Permian-Triassic reservoirs of the Persian Gulf. J Petrol Sci Eng 200:108356

Tiab D, Donaldson EC (2015) Petrophysics: theory and practice of measuring reservoir rock and fluid transport properties. Gulf professional publishing

Wright HT, Woody LD (1955) Formation Evaluation of the Borregas and Seeligson Field: Brooks and Jim Wells County Texas. In: Symposium on Formation Evaluation, AIME. pp 27-28

Xu C, Torres-Verdin C (2013) Pore system characterization and petrophysical rock classification using a bimodal Gaussian density function. Math Geosci 45:753-771

Yong H, Xinghe Y, Gongyang C, Shengli L (2012) Classification of the average capillary pressure function and its application in calculating fluid saturation. Petroleum Exploration and Development 39:778-784

ZHAO G, ZHU J, Guan L (2008) Method of applying capillary pressure data to calculate initial oil saturation. Journal of China University of Petroleum (Edition of Natural Science) 12

Publisher's Note Springer Nature remains neutral with regard to jurisdictional claims in published maps and institutional affiliations.

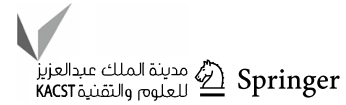

